\title{
What does Southeast Asia want from Australia?
}

Edition 9, 2022

Melissa Conley Tyler and Sarah Allan

DOI: 10.37839/MAR2652-550X9.2

In recent times Australia has been giving increasing priority to its relations with Southeast Asia. Just two years ago the Pacific Step-up was taking resources from Southeast Asia to the extent that some bemoaned that it had caused a Southeast Asian 'Step Down'. There were calls for Australia to 'Step Up in Southeast Asia 'as the protective membrane for Australia's own prosperity and security.'

Then in 2020 Australia announced its largest funding commitment to Southeast Asia since the 2004 tsunami. Momentum continued into 2021 with Comprehensive Strategic Partnerships agreed first with Malaysia and then with Association of South East Asian Nations (ASEAN) at the historic first annual ASEAN-Australia Leaders' Summit. This has been matched by increased bureaucratic focus, with the Department of Foreign Affairs and Trade recently expanding its focus on Southeast Asia from one to two divisions located in a new 'Southeast Asia and Global Partners Group'.

Will this activity lead to deepened Australia-Southeast Asia engagement? The answer will depend crucially on how closely Australia aligns with Southeast Asia's needs and interests. Greater alignment will build a growing sense of solidarity while divergence in strategic priorities will see Australia and Southeast Asia drift further apart. So, what does Southeast Asia want from Australia?

The authors have been involved in an Asia-Pacific Development, Diplomacy and 
Defence Dialogue (AP4D) program looking at how Australia can shape a shared future with Southeast Asia. As part of this, data was gathered on what Southeast Asian experts say the region wants from Australia. We reviewed published sources, analysed the output from various Australia-Southeast Asia dialogues and conducted an online session with invited experts from across the region to gather their views. This enabled us to capture a particular elite foreign policy viewpoint: of academics, think tank experts and current and former diplomats who are involved in contemporary policy debates. While there are limitations to this approach-for example, it only captures the views of those who have actively engaged on Australia's role in the region-it does provide valuable insights into the views of some influential voices in the region. Despite the diversity of the region and variations in emphasis, three main themes emerged.

\section{Don't treat Southeast Asia as a theatre of great power competition}

One of the key challenges facing the region is the great power competition between China and the United States. Both Southeast Asian states and Australia share concerns, but they see the problem differently. As senior analyst at the Australian Strategist Policy Institute (ASPI) Huong Le Thu summarises pithily:

'While Canberra is ... concerned about intensifying great-power competition, its primary narrative is about the challenge posed by China, rather than the challenge posed by both the US and China, which is how the ASEAN nations see the problem.'

Southeast Asian countries do not want to pick a side. The official response of ASEAN to the rise of economic and military powers is that it 'requires avoiding the deepening of mistrust, miscalculation, and patterns of behaviour based on a zerosum game.' In opening the 37th ASEAN Summit in 2020, Vietnam's then Prime Minister Nguyen stressed the need for ASEAN to be 'steadfast in pursuing a balanced and harmonious approach so as to maintain its centrality without being 
swayed or drawn into the regional and international maelstroms.'

That's not to say that Southeast Asian countries are not concerned about China, or that they are all equally even-handed. In the words of distinguished former Singaporean diplomat Bilahari Kausikan:

'China's size and economic weight no doubt stoke anxieties among its Southeast Asian neighbours, worries that have been accentuated by the aggressive foreign policy of President Xi Jinping. But those concerns must be weighed against the necessity of maintaining political and economic ties with Asia's biggest power. No country in Southeast Asia will accept an exclusive relationship with China or the United States.'

As Malaysian academic Nurliana Kamaruddin explains, Southeast Asian countries do not want to be caught in the middle as they rely on both major powers as a matter of ensuring survival:

'in any conflict between these two major powers, the losers, inevitably, will always be the small, weaker countries caught in the middle. If the major powers seem set on competition, the ASEAN member countries will continue to hedge and make foreign policy decisions based on their interests and immediate perceived benefits.'

By contrast, Australia's formal security alliance with the US-reinforced by an enhanced trilateral security partnership between Australia, the US and the United Kingdom (AUKUS) - mean that Southeast Asians generally view Australia as more US-aligned. Indonesian think tank expert Evan Laksmana explains that Australia is perceived to act as part of US efforts to challenge China. In turn, this can be interpreted as Australia stoking tensions and undermining stability. Malaysian think tank expert Shahriman Lockman believes that this will always be a factor for Australia in the region: 'Southeast Asians will never quite understand the depth of the relationship between Australia and the US and as a result they will make quick conclusions about Australia and America.' It is easy to paint Australia's approach as meeting US and Australian rather than Southeast Asian goals. 
In part, this may be a defensive reaction. Southeast Asian interlocutors don't want to be reminded of how difficult a position Southeast Asia is in. Australia approaching the region through the lens of great power competition brings these fears to the surface. Australia needs to acknowledge this fear within the region and show that it is willing to act in the region's best interests.

Both Southeast Asian and Australian experts advise Australia to avoid narratives that frame Southeast Asia as a battlefield: the region is utterly disinterested in a competition of systems and wants to be engaged and valued in its own right. In the words of Indonesian think tank expert Lina Alexandra: 'Southeast Asian countries do not want attention in the region simply to be because of the 'China factor', but based on building genuine relations to understand its closest neighbours better.' Southeast Asian countries want to be treated as partners instead of pawns in a greater strategy.

The consistent advice to Australia is to treat Southeast Asian partners as autonomous actors, in line with their self-conception of agency: they don't want to see themselves as victims of geopolitical and geostrategic shifts.

\section{Respond to Southeast Asia's priorities}

A danger for any country is that it will be driven by its own priorities and not by those of the partners it attempts to engage with. The second consistent message from Southeast Asia to Australia is to focus its engagement squarely on the needs of the region. As one participant put it during a consultation session, 'The frame of reference should be what's useful to countries in the region; Australia being responsive to the countries in the region.'

In the wake of COVID-19, the immediate need is for recovery. In the words of Vietnam's then prime minister when opening the ASEAN Summit: 'We are going through incredibly difficult times in which the livelihood and lives of our people are under threat by the COVID-19 pandemic while the economic and social life is in 
disarray, and further aggravated by severe natural disasters, storms, floods and droughts.'

In the assessment of the Asian Development Bank, recovery is uneven: 'Recovery continues to gain momentum in developing Asia, but recent outbreaks of COVID-19, driven in part by new variants, drag on growth in several economies.... Vaccine rollouts are progressing in many economies, but developing Asia is still far from achieving herd immunity.'

The top priorities for Southeast Asia after the immediate health issues are to reverse economic downturns and revive development. The impacts of COVID-19 present a major challenge to the region especially in the long term for issues such as unemployment, inequality and mental health. This is coupled with long-term economic scarring which will continue to exacerbate the issues of poverty and unemployment. In the words of Malaysian academic Nurliana Kamaruddin, 'What ASEAN as a region requires is help from all the major powers. Surviving and recovering from the ravages of the COVID-19 pandemic will be the focus for Southeast Asia for the foreseeable future.'

Australia has shown that it understands the scale of damage across the region and has responded, but development assistance to the region had previously been slashed. Australia's reaction to COVID-19 also presents a challenge as it is perceived to have cut itself off from the region through border closures. This has been a particular issue in education as Australia has been a strong education partner for Southeast Asia, so this has had widespread impacts.

Some of the Southeast Asian experts consulted by AP4D called on Australia to commit to long-term development policies which lead to permanent change. This would be particularly useful in mainland Southeast Asia, which has a predominantly young population which need jobs, decent work, training and capacity-building.

Across the region, infrastructure investment will be key to post COVID-19 growth. Australia is not seen as a major player in this space compared to China, Japan and 
South Korea, but interestingly, one of the those consulted called on Australia to be a partner to strengthen civil society to work with investors, particularly Chinese investors. This would involve engagement with civil society-including education, technology and think tanks-to help them gain an understanding of the effectiveness of investments and how to ensure their success.

Looking ahead, Southeast Asia is very aware of the cascading impacts of climate change. The region requires support for disaster responses, such as through the ASEAN Coordinating Centre for Humanitarian Assistance on disaster management. There should be importance placed on capacity building through joint training to ensure the military and security sectors are prepared for disaster responses.

And this doesn't mean that other issues have gone away. There is a continuing need to work with Southeast Asia to combat extremism and respond to forced migration.

Of course, the key issues will differ for each partner. Philippine academic Charmaine Misalucha-Willoughby sees Australia-Philippine bilateral engagement as being wellfocused on the top national security issues as perceived by the Filipino Strategic Community: the COVID-19 pandemic; terrorism and violent extremism; the communist insurgency; cybersecurity; and disinformation.

As one among many players, and with limited resources, Australia needs to be strategic if it wants to make a valuable contribution. This may mean focusing on an emerging area are such as digital and tech and investing smartly and generously.

Engaging with Southeast Asia as a partner will allow the region to increase its capacity to address challenges and will in turn allow Australia to benefit from the future prosperity of the region.

\section{Connect on the basis of shared interests}

Finally, there was a consistent call to base Australia's engagement with the region 
on shared interests. This requires a change in rhetoric from what Southeast Asia 'needs' from Australia to how shared interests can foster a mutually beneficial relationship that aligns with Southeast Asian priorities.

The shared interests with some Southeast Asian countries are clear. For example, Singaporean think tank expert Chen Chen Lee see Australia and Singapore as 'natural partners' that see eye-to-eye on many issues including the importance of an open rules-based and inclusive multilateral trading system.

In this case, one option is to focus less on shared values and more on 'shared principles' for cooperation in the Indo-Pacific. The Asia Society's Richard Maude defines this as 'respect for national sovereignty, the peaceful settlement of disputes, non-use of coercion and respect for international law, especially in the UN Convention on the Law of the Sea.' But there are many countries in Southeast Asia with which Australia does not have this level of consonance.

Australia can also extend its influence beyond governments to their people through engagement with civil society. There has been an illiberal turn in Southeast Asia, exacerbated by COVID-19.

According to Bangkok-based human rights campaigner James Gomez, 'Over the past two decades, governments have repeatedly taken opportunities during crises to deepen their authority. As COVID-19 subsides, the inexorable heightened state surveillance will be the latest authoritarian residue to afflict Southeast Asia. Civil society needs to prevent these authoritarian residues" from building up in order to reverse the regression of democracy in Southeast Asia.' His colleague Yawee Butrkrawee warns that if Australia sidesteps these issues, it will be seen by civil society as being insensitive: 'The Thailand example showcases Australia's country level engagement in Southeast Asia. It is mainly elite based and out of touch with democratic front liners in the country.'

While some inconsistencies are inevitable, it is important to continue to implement Australia's stated human rights aims in the region, including through engagement 
with civil society.

Australia's links outside the region-particularly through the Quadrilateral Security Dialogue between the US, India, Japan and Australia (the Quad) and the newlyannounced AUKUS initiative - have created something of a problem for Australia in creating a narrative of shared interests with ASEAN countries. Some see this as evidence that Australia is looking outside Southeast Asia for shared interests.

Indonesian academic Evi Fitriani explains this dilemma in the context of Australia and Indonesia, which 'want to maintain the momentum of good relations deepened previously by President Joko Widodo and former PM Malcolm Turnbull, but on the other side, compelled to take pragmatic moves and clutching to reliable partners and finding out that they do not belong to each other's reliable clubs.'

Australia's reliance on groupings such as the Quad and AUKUS have led to calls for Australia to prioritise its relationship with ASEAN and support ASEAN centrality rather than compete with ASEAN platforms. One consultee described the Quad as taking agency and autonomy away from Southeast Asian countries. While reactions to AUKUS in the region have been mixed, one lesson that has been widely drawn is that it undermines ASEAN centrality.

An important message to send to the region is that while there may be significant differences in Australia's foreign policy approach, there is a convergence of shared interests. Australia doesn't have to be neutral to be useful.

When it engages with Southeast Asia, both regionally and bilaterally, Australia should consistently reinforce a narrative focused on shared interests with the region. Perhaps the best statement of this is the Joint Statement of the 2018 ASEANAustralia Special Summit:

'we are partners with a vital stake in a dynamic region undergoing major changes. We commit to intensify our shared work to shape a secure and prosperous region for our people.' 


\section{Conclusion}

How should Australia respond to the views outlined above? We suggest it means that Australia should focus on the long game. What Australia may want is a region that maintains its sovereignty and resilience by pushing back against Chinese encroachment. But the way to achieve this is not by pushing a geopolitical competition agenda. It is by becoming a trusted partner.

This means using all the tools of statecraft to align with the region's long-term interests. As AP4D Co-Chair Michael Wesley puts it,

'The Australia-US goal in Asia is to convince China's neighbours that it is possible to retain their strategic independence even as they remain tied economically to the region's largest economy. To do this, we need a greater investment in diplomacy and development assistance, not cuts to these resources.'

To build confidence Australia needs to demonstrate a comprehensive and sustained long-term strategy for its engagement in the region through integrating development, diplomacy and defence. The region wants to see a lasting commitment.

An ideal Australia could work towards is one endorsed by Philippine Foreign Affairs Secretary Teodoro L. Locsin Jr who described Australia as 'the anchor of ASEAN, hanging down there as a steadying force in the rising and ebbing geopolitical tides.' His vision of Australia is as a stabiliser, not a destabiliser. This is what Southeast Asia wants from Australia.

Melissa Conley Tyler is Program Lead and Sarah Allan is a former researcher at the Asia-Pacific Development, Diplomacy \& Defence Dialogue (AP4D), a new initiative bringing together individuals and organisations to reimagine Australia's international relations. This piece is based on research for the AP4D program 'Shaping a shared future - deepening Australia's influence in Southeast Asia and the Pacific' funded by the Australian Civil-Military Centre. Melissa is an Honorary 
Fellow of the Asia Institute.

Image: ASEAN-Australia Leaders' Plenary Opening Remarks Room, Sydney, 2018. Credit: ASEAN/Australia Special Summit 2018. 